\title{
Role and Measurement of Fair Valuation in the Hungarian Credit Institution Sector*
}

\author{
Tamás Szücs - József Ulbert
}

The crisis demonstrated that the role of the accounting standards applicable to fair valuation may be particularly important in the credit institution sector. The paper examines the influence exerted on the balance sheets of the Hungarian credit institutions by the fair valuation and the international and the Hungarian economic policy regulatory changes relating to valuation. We place special emphasis on examining whether the foreign-owned credit institution subsidiaries operating in Hungary and their parent banks responded differently to the challenges posed by the crisis. We elaborated a method for the measurement of the real involvement and using this we examine how the fair value involvement of the Hungarian credit institution sector has changed before, during and after the crisis. Generalising the problem, we found that the degree of the fair value involvement may represent an additional risk factor upon assessing the credit institutions' operational efficiency and that the Hungarian subsidiaries followed a slightly different path than their parent banks.

Journal of Economic Literature (JEL) codes: G01, M40, M41

Keywords: crisis, fair value accounting, fair value hierarchy

\section{Need for fair value}

When examining the history of accounting rules, the thought of valuation at fair value first emerged in the early ' $80 \mathrm{~s}$. In parallel with the spread of globalisation, the world's financial markets were accomplished and commenced an unprecedented development. New markets appeared on the scene, which also offered new investment opportunities; thereby, adding colour to the spectrum of traditional transactions.

In addition to the classic transactions, the innovative, novel financial products and the increasingly complex financial instruments gained growing importance. The

\footnotetext{
* The views expressed in this paper are those of the author(s) and do not necessarily reflect the offical view of the Magyar Nemzeti Bank.

Tamás Szücs is the Senior Associate Professor of the Faculty of Business and Economics, Institute of Finance and Accounting, University of Pécs. E-mail: tomi@ktk.pte.hu.

József Ulbert is the Habilitated Associate Professor of the Faculty of Business and Economics, Institute of Finance and Accounting, University of Pécs. E-mail: ulbert@ktk.pte.hu.
}

The Hungarian manuscript was received on 21 December 2016.

DOI: http://doi.org/10.25201/FER.16.3.5173 
understanding and pricing of these products, as well as the determination and modelling of their value, represents an increasing challenge for investors.

The acceleration of the spreading of novel financial instruments in the financial markets was fuelled by the perceivable growth in risk in certain risk segments, as the innovative products were often meant - as claimed by the architects of these products - to provide protection against the increased risk.

It is also beyond doubt that one driver of the development of capital and money markets could have been the goal to expand market turnover, since this carried the opportunity for the creators and distributors of the innovative products to tap the revenues received here via various fees and services.

The escalation of these processes spanned over two to three decades, which, as a matter of course, was accompanied by rise in prices and the fact that the measurement of capital market's performance increasingly drifted apart from real economy performance. The market's value measurement function raised increasing doubts, particularly in the case of those novel products that had no underlying real economy performance at all.

The legislation, the financial methodology and the accounting profession alike were unable to keep pace with this rate of development, hence the investors' increasing demand to determine the fair value of these novel products and to state these valuations on the asset side of the balance sheets appeared at the same rate as the rate of these products' "sneaking into" the balance sheet and income statement of the investors (first and the most intensively it could be observed at the credit institutions, and particularly at the investment banks).

Beneish (1999) in his paper rang the alarm bells already before the turn of the millennium. In his opinion, fair valuation may be a good way to manipulate financial statements, as the incomes originating from the revaluation of certain holdings may entail unjustified rises in equity prices.

In this respect, albeit slightly late, from the second half of the '80s the company valuation and the accounting profession started to move in the same direction. In the course of determining the value of companies, the methods based on the principle of yield value, trying to measure the value creation function of future yields, also appeared in addition to the asset-based valuations. In parallel with this, the market-based, fair valuation started to replace the cost-based valuation in the international accounting practice as well (Shaffer 2012).

Despite the parallelism, the financial approach - with the introduction of the yield value principle - offered a different response to the challenge than the accounting profession, which still sees the solution in the pricing of assets. That is, in the case of finances the emphasis shifted from the assets to the measurement of the assets' yield earning capacity (Bélyácz 2013). 


\section{The fair value concept}

According to Regulation 1606/2002/EC of the European Parliament and of the Council, as of 1 January 2005 (in Hungary as of 2007) the consolidated financial statements of all listed companies must be prepared in accordance with the international accounting standards, in the course of which the application of fair valuation is mandatory.

This directive specifies fair value as the amount for which an asset can be exchanged or a liability can be settled between well informed parties intending to conclude a deal, within the framework of an arm's length transaction.

Due to its general formulation and the practical problems relating to its applicability, this definition has been heavily criticised from the start both in the technical literature and in practice.

According to Barth (2004), the estimation of the fair value of a company's assets varies in time, as market considerations do appear in it, that is, it loses its stability in time, while volatility should be regarded as an additional risk factor, as in the ascending, growth phase it may serve as self-justification for the management, while in the descending phase it may escalate the processes. In the case of assets that have no real or have only limited market background, valuation is based on models that apply uncertain, often impractical conditions, hence the estimation of the value cannot be free from errors either; accordingly, fair valuation may only be applied in a steadily liquid market environment, where nothing hinders the participants from obtaining information.

According to Hitz (2007), the conditions of applying fair valuation are idealised; thus, the market-based valuations created with the use of these are also only hypothetical, as the definition does not specify, for example, whether it is a purchase or sale transaction. It also does not provide information on the date to be considered relevant for the definition of the balance sheet value, or on the exact meaning of the "arm's length" market condition criterion.

These negative factors are only partially offset by the fact that the definition also made it possible to state such assets in the balance sheet that were formerly offbalance sheet items, and as such remained invisible for the investors (Bosch 2012).

Bromwich (2007) also provides a good summary of the, often not too practical, assumptions underlying the definition of fair value. 


\section{Table 1}

Impracticable conditions of fair value

\begin{tabular}{|c|c|}
\hline Group & Underlying consideration \\
\hline \multirow[t]{3}{*}{ 1. Prices } & $\begin{array}{l}\text { a) The prices used upon the measurement of fair value are based on the market, } \\
\text { irrespective of the trading objective of the economic agent. }\end{array}$ \\
\hline & b) The price is a sales (exit) price. \\
\hline & c) The prices do not contain the transaction costs. \\
\hline \multirow[t]{2}{*}{ 2. Market } & a) The transactions take place on the usual (primary) market (highest volume and activity). \\
\hline & $\begin{array}{l}\text { b) If several markets exist, the most advantageous will be the one where profit } \\
\text { maximisation can be achieved. }\end{array}$ \\
\hline \multirow{5}{*}{$\begin{array}{l}\text { 3. Market } \\
\text { participants }\end{array}$} & a) Unrelated, i.e. independent parties. \\
\hline & $\begin{array}{l}\text { b) Well-informed participants, able to understand the basic attributes of the asset } \\
\text { component and the transaction. }\end{array}$ \\
\hline & $\begin{array}{l}\text { c) When obtaining the necessary information, they act with due diligence and do } \\
\text { their best to understand the information. }\end{array}$ \\
\hline & d) The individual transactions are without any compulsion. \\
\hline & $\begin{array}{l}\text { e) The individuals have the capacity and willingness necessary for concluding the } \\
\text { transaction. }\end{array}$ \\
\hline \multirow{7}{*}{$\begin{array}{l}\text { 4. The } \\
\text { presumed usage }\end{array}$} & a) The financial instruments are clearly defined by their cash flow structure. \\
\hline & $\begin{array}{l}\text { b) In the case of assets, estimation of the offer price that represents the most } \\
\text { profitable usage at the time when the valuation is performed by the market } \\
\text { participant, which is: }{ }^{1}\end{array}$ \\
\hline & - in-use valuation (can be used together with other assets): defining the highest use value; \\
\hline & $\begin{array}{l}\text { - in the case of (independently usable) exchange utilisation value defined on the basis } \\
\text { of individual valuation. }{ }^{2}\end{array}$ \\
\hline & c) Of the prices mentioned in point b) the fair value will be the highest one. \\
\hline & $\begin{array}{l}\text { d) The use is possible in physical terms, acceptable in legal terms and feasible in } \\
\text { financial terms. }\end{array}$ \\
\hline & e) The transfer of liabilities is possible under identical credit risk (default risk). \\
\hline \multirow{3}{*}{$\begin{array}{l}\text { 5. Accounting } \\
\text { assumptions }\end{array}$} & Traditional accounting assumption: \\
\hline & $\begin{array}{l}\text { - The measurement must be performed in the case of all separable asset } \\
\text { components and the aggregated groups of those. }\end{array}$ \\
\hline & $\begin{array}{l}\text { - The measurement takes account of the condition and location of the asset, if } \\
\text { relevant. }\end{array}$ \\
\hline
\end{tabular}

Source: Bromwich (2007:53).

While the general market and economic condition was reliable and stable, the definition, despite all of its faults, in fact remained workable. The number of problems started to rise in parallel with the accomplishment of the new crisis.

\footnotetext{
${ }^{1}$ The assumption of the in-use valuation premise is that market participants want to use the asset together with other assets; thus, the fair value of the assets is influenced, typically increased, by the synergies among the assets.

${ }^{2}$ In the case of the in-exchange valuation premise it can be assumed that the asset can be utilised on its own and this is the way the market participants can realise the maximum profit with it.
} 


\section{Fair value and crisis}

Has the possibility of fair valuation opened Pandora's box, that is, has it contributed to the development and later on to the escalation of the crisis, or quite the contrary, it opened the possibility of managing the crisis?

Several authors believe (Wallison 2008; Whalen 2008) that the procyclical nature of fair valuation could have been the main cause of the crisis. They emphasise that fair valuation is the primary reason for the unforeseen fall in property value and for the, also unexpected, growth in the instability of financial enterprises. The application of FASB ASC $820^{3}$ and the fair value-based calculation of the banks' capitalisation caused a downward spiral in property value and contributed to the major fall in solvency. The classification of instruments held to maturity as trading assets was a solution that served business interests. According to the related criticism, often even assets without objective market price were reclassified.

According to other opinions (Pozen 2009; Le Pan 2008), fair value accounting cannot be the cause of the crisis. Moreover, certain opinions go beyond this and emphasise that it is much easier for the managers of banks and insurers to put the blame on the accounting standards rather than on the capital adequacy regulations controlled by the credit institutions. The fair value accounting provided early warning of the impacts and problems that appeared as a result of the incorrect decisions relating to the secondary mortgage market loans and the credit default swaps (Rerolle 2008).

According to Power (2008) the authors of the standard should have spent much more time on the revision of the valuation in order to make the fair valuation model usable in a much wider domain. Simply, it was introduced too early.

In their works, Veron (2008) and Shamkuts (2010) designate liquidity shortage and procyclicality as the two important problems of fair valuation. Market price is essential for the definition of the fair value. If this is not available, companies turn to different models, with the help of which they attempt to forecast future processes. This is an acceptable effort, with relative reliability, in a predictable and calculable economic environment, while it is not in a crisis period. They argue for the pressing need to change the regulations, as the present regulation does not calculate with the data loss arising from the potential negative effects and the impacts thereof on the financial statements. They mentioned as a shortcoming to be eliminated that the present measurement system must be adjusted in line with the market conditions and supplemented with proper information in the statements.

Laux and Leuz (2009a; 2009b) believe that fair valuation cannot be made liable for the stimulation of the crisis and it should be regarded as nothing else but a potential

\footnotetext{
${ }^{3}$ Fair valuation standard of US GAAP, formerly FAS 157.
} 
measurement model. In their opinion the present rules alone do not represent the source of the crisis, but their interaction with other institutional frameworks may cause problems. In addition, they emphasise that the return to Historic Cost Accounting (HCA) cannot be regarded as a solution, as it reflects the current value of the asset to an even lesser degree. The solution may only be a short-term one: recognising a smaller amount of impairment. However, the critics of fair valuation must not disregard the fact that the model provided early warning signs of the approaching crisis, forcing banks to take the necessary measures. That is, despite all of its faults, fair valuation had effectively reduced the severity of the crisis.

Allan and Carletti (2008) believe that the main problem with fair valuation is that in a not sufficiently liquid market environment it is extremely difficult to estimate the fair value and in most cases we end up with an unreliable result. In this approach, in fact fair value can be defined as a kind of indicator of the liquidity level of the market. According to Gorton (2008), the other essential problem is that the fair valuation mechanism exerted pressure on credit institutions, and as a result of the estimation process built on uncertain future forecasts, often recognizing such impairments which led to the undervaluation of certain asset components.

Laux and Leuz (2010) refute the American position according which, with the exception of a few large banks, fair valuation had limited role in the changes of the banks' income statement and solvency capital, as the banks decided on the increase of their subprime exposure independently and the fair valuation methodology cannot be blamed for the problems. Naturally, the topic was in the focus not only in the professional circles, taken in narrow sense. David Dodge, former governor of the Bank of Canada and Steve Forbes, chairman of Forbes Media vehemently asserted that fair valuation accelerated and boosted the crisis (McFarland-Partridge 2008). Nicholas Sarkozy (2008), in a speech delivered in 2008, also emphasised that "banks are subjected to the accounting rules, which do not provide sufficient guarantee for the avoidance of risk; moreover, in the case of a crisis they exacerbate the situation rather than absorbing the strength of the shock."

According to the former chairman of the U.S. Federal Deposit Insurance Co, William Isaac, the application of fair valuation affected the banks' capital to an unreasonably high degree, which contributed to the accomplishment of the crisis and to the economic downturn (Magnan 2009).

\section{Fair valuation after the crisis}

The most important lesson learnt from the crisis in terms of fair valuation is that rational regulation is essential for the maintenance of financial stability. The justification of this stems from the fact that the profit-oriented behaviour of the credit institutions may entail negative impacts (Pitz - Schepp 2013). 
As a result of the practical experiences and the aforementioned criticism, the IFRS 13 standard $^{4}$ was issued in May 2011 and it is effective from 1 of January 2015. It prescribes a uniform theoretical framework for the determination of fair value, which can be used both for financial and non-financial assets. IFRS 13 defines fair value as follows: "The price that would be received to sell an asset or paid to transfer a liability in an orderly transaction between market participants at the measurement date."

Upon determining the fair value, certain key conditions had to be stipulated to ensure the reliability of the valuation result. The economic agent must determine

- the fair valuation units of account (i.e. the evaluated asset or liability),

- the primary market where the ordinary transaction would take place and the assumptions that would be applied by the market participants,

- the highest degree and best utilisation of the assets in the case of non-financial assets, considering whether the assets may be used in combination with other assets or on their own.

The new standard emphasises that fair value is a market-based valuation. In the case of certain assets and liabilities, observable and comparable market transactions or market information may be available. According to Kovács (2012), the new standard emphasises, in addition to the precedence of market valuation, sector neutrality. In case of other assets and liabilities the appraiser may not have these. Irrespective of this, the purpose of fair valuation is the same in both cases: to estimate the price that would be received to sell an asset or paid to transfer a liability in an orderly transaction between market participants at the measurement date under the existing market conditions.

This value is often referred to as "liquidation value". In this sense, fair value means an exit price, realised at the time of the valuation between relevant market participants (the owner of the asset or the obligor of the liability).

The economic agent must use valuation methods suitable under the given circumstances and in respect of which sufficient data are available for the determination of the fair value, maximising the use of the observable input data and minimising the use of unknown information. The IFRS 13 (with some exceptions) requires the economic agent to group these valuations and disclosures into a "fair value hierarchy" consisting of three levels, which is based on the nature of the inputs.

\footnotetext{
${ }^{4}$ International Financial Reporting Standard 13 - Fair value measurement standard
} 
Level 1 - Applies to financial assets and liabilities exchanged on an identifiable, active market. The realisation of the conditions is subject to the simultaneous fulfilment of the following two conditions: a) an existing market, where there is demand for and supply of the assets and liabilities; b) the transaction could be executed at the price specified by the economic agent at the given time of the valuation.

Level 2 - Such assets are allocated to this level that are not the quoted prices related to the asset or liability, applied by Level 1 (derived directly or indirectly from the market price). Due to the not fully independent price formation, these instruments cannot be allocated to Level 1. Upon the categorisation of this level the following cases are typical: a) the quoted price for the assets and liabilities similar to the given instrument is known; b) the quoted price for the assets and liabilities that are the same as or similar to the given instrument is known, but the market does not function at the time of the valuation; c) in addition to the quoted price, other indicators may also be identified in respect of the given instrument: interest rate, yield curve for the given subscription period, volatility, fastness of prepayment, lossrelated restrictions, credit risk, insolvency ratio, etc.; d) the price of the instrument can be derived from the market processes with the use of statistical methods (e.g. correlation, regression, averages).

Level 3 - If no relevant, observable inputs are available for the given instrument, unobservable parameters should be used for the determination of the fair value; thereby, such situations may be taken into consideration where the market activity is small at the time of the valuation. The purpose of the valuation at fair value remains the same: to determine a realistic exit price at the time of the valuation from the point of view of the market participant that is the owner of the asset or the obligor of the liability. Accordingly, the unobservable parameters must reflect the conditions that the market participants would use upon the pricing of the asset or liability, including in particular the assumptions related to risk. The economic agent is obliged to use the best information available under the given circumstances, which in part may also include the economic agent's own data.

The valuation logic of the first two levels is essentially built on market information (Mark to Market). The reliability of the obtained results is confirmed by the market processes. However, the valuation approaches of Level 3 are primarily based on model calculations (Mark to Model), for which IFRS 13 recommends several valuation methods to the economic agents: market-, cost- (historic cost) or yieldbased approach ${ }^{5}$ (Takács 2014 and 2015).

\footnotetext{
${ }^{5}$ Yield-based valuation means the discounted profit or the discounted cash flow.
} 
After the publication of the standard (at the end of the more severe phase of the crisis), the technical literature dealing with fair valuation and the practice formulated much more polished and diverse criticism, free from political impacts, than before the crisis, focusing more on technical issues rather than on looking for somebody to be blamed.

The post-crisis technical literature is also divided in terms of how they judge fair valuation, but new elements also appear, supplementing the previous criticism. Of these new trends, perhaps the most important one for the essence of our paper is that fair valuation can be interpreted as an additional risk, but also as an opportunity. For example, according to the analyses performed by Reidl and Serafeim (2011) accounting for the financial instruments at fair value increases the cost of capital, i.e. entails a higher level of risk. Shaffer (2012) emphasises that fair valuation is not always objective, clear or transparent. It can lead to erroneous conclusions particularly in the case of inactive markets, in the absence of liquid markets or during the periods of market crises. On the other hand, according to other authors (Barth et al. 2012) fair valuation is not the direct cause of the crisis, as the valuation performed by it represents unrealised gain, hence it cannot be taken into consideration as the financing base of dividends. They also mention that fair value-based mentality (contrary to the historic cost) is able to treat the concept of good and bad news equally correctly. Having analysed British and German companies Christensen and Nikolaev (2013) found that in selecting the valuation method for non-financial assets economic and financial regulations are much more important than the market processes.

Greenberg et al. (2013) provide a good summary of the more sophisticated postcrisis approaches. In their paper they basically formulate three objections to fair valuation:

a) the notion of objective "market price" is very confusing, and may be particularly misleading in less liquid markets;

b) the mechanism of fair valuation may contribute to a larger degree to the infection of the given bank's financial investments, if they have tight correlation with certain investment portfolios or with the financial relations of the network partners;

c) in crisis situations fair valuation may often have coercive effect on the sale of certain assets, even though a higher price could be realised by holding them longer. 
On the whole, it can be established that the relevant technical literature and practice have a rather diverse approach to the fair valuation methodology. In the post-crisis technical literature there is no such opinion that would be expressly condemning. Not even in the approaches labelling it as the trigger of the crisis. On the other hand, we did not find such opinions either that would have solely emphasised that the crises could be addressed by fair valuation. This is due to the fact that most authors acknowledge the advantages of fair valuation compared to historic cost. On the other hand, the disadvantages that seemed to have been reinforced by the crisis are also clear.

The authors of this paper tend to take the middle course, according to which fair valuation may have contributed to the outbreak of the crisis, but it surely cannot be designated as the single cause. The other side also has its truth, as in expert hands fair valuation may indeed be capable of addressing problems. This duality can be also traced in our empirical research related to Hungarian credit institutions. However, it cannot be disputed that despite all of its errors and shortcomings, fair value has become/is becoming an increasingly applied asset valuation method. Its role has particularly appreciated in the credit institution sector, since this sector has also been in the centre of the crisis.

\section{Measurement of the Hungarian credit institution sector's fair value involvement}

The international empirical surveys relating to fair valuation usually examine the relevance of the values at the individual levels (Bagna et al. 2014; Kolev 2008 Goh et al. 2009; Song et al. 2010). In our future researches we also plan more detailed value relevance tests in the Hungarian credit institution sector, but for the time being, in this paper we deemed it more important, as a foundation of the topic, to present the weight of fair valuation on the asset and liability sides of the balance sheets in the Hungarian credit institution sector.

We elaborated a potential measurement method for the fair value involvement and sought answers to the following questions.

a) How does the degree of fair value involvement change in the balance sheet of the Hungarian credit institutions?

b) Is it possible to observe before, during and after the crisis typical patterns in the temporal change of fair value involvement, i.e. could the degree of the involvement be indicative of the imminent crisis or should we rather treat these patterns as causes triggering the crisis? 
c) Are there significant differences in the patterns of involvement between the subsidiaries and the parent companies?

d) What kind of special features can be observed in the involvement patterns in respect of OTP, as a leading Hungarian bank?

\subsection{Database, transformation and time horizon of the empirical survey}

The database was compiled from the annual consolidated financial statements for ten years (2006-2015) of OTP, and further five dominant actors of the Hungarian credit institution sector and their parent banks ${ }^{6}$, hence it contains balance sheets and income statements of the same structure in accordance with IFRS ${ }^{7}$. The tenyear time series was broken down into four periods (Table 2), as in this way we can demonstrate the periodic changes in the effects of the crisis and fair valuation.

\section{Table 2}

Periods of the empirical analysis

\begin{tabular}{l|l} 
Pre-crisis period & 2006-2008, 3 years \\
\hline Crisis period & 2009-2010, 2 years \\
\hline First post-crisis period & $2011-2012,2$ years \\
\hline Second post-crisis period & $2013-2015,3$ years \\
\hline
\end{tabular}

From the annual nominal data we calculated periodic average annual data for the above periods by simple arithmetic averaging, after which we expressed the appropriate values of the asset and liability summary rows as a percentage of the prevailing balance sheet totals. The data of the subsidiaries and the parent banks were averaged, thus where the data disclosure refers to subsidiary it means the average of the subsidiaries.

\subsection{Concept and measurement of fair value involvement}

While examining the annual reports we found that the fair valuation methods could be traced only in the following balance sheet rows ${ }^{8}$.

\footnotetext{
${ }^{6}$ Intesa Sanpaolo Group - CIB Bank Zrt., Raiffeisen Zentralbank Österreich AG - Raiffeisen Bank Zrt., Bayerische Landesbank (continuing the data series also after the transfer of MKB to state ownership!) - MKB Bank Zrt., KBC Group - K\&H Bank Zrt., UniCredit Group - UniCredit Bank Hungary Zrt.

${ }^{7}$ In case of Hungarian credit institutions the data are based on the annual reports uploaded to www.ebeszamolo.hu (downloaded on 5 March 2016), while in the case of the parent banks they were collected from the annual reports published on the websites. The authors provide access to the database after prior registration. If you are interested, please contact us by e-mail.

${ }^{8}$ On the asset side it was not possible to break down the data in an unambiguous way, hence we treated the affected rows together.
} 


\section{Table 3}

\section{Scope of involvement in the balance sheets}

\section{Assets involved}

Financial assets recognised against profit/loss

Ratio of derivative financial instruments

Ratio of financial investment available for sale

\section{Liabilities involved}

Liabilities recognised against profit/loss

After the described transformations of the input data, we obtained the fair value involvement's primary indicator, which shows to what extent the fair valuation methodology was typical for the given bank, or rather for the average of the banks, on the asset and liability sides.

The primary involvement is expressed as a percentage of the balance sheet total and for the time being does not contain the internal structure of the fair value by levels.

Figures 1 and 2 show the temporal change of the primary involvement values, obtained after aggregating the input data according to the above method, on the asset and liability sides.

\section{Figure 1 \\ Temporal change of fair value involvement on the asset side as a percentage of the balance sheet total}

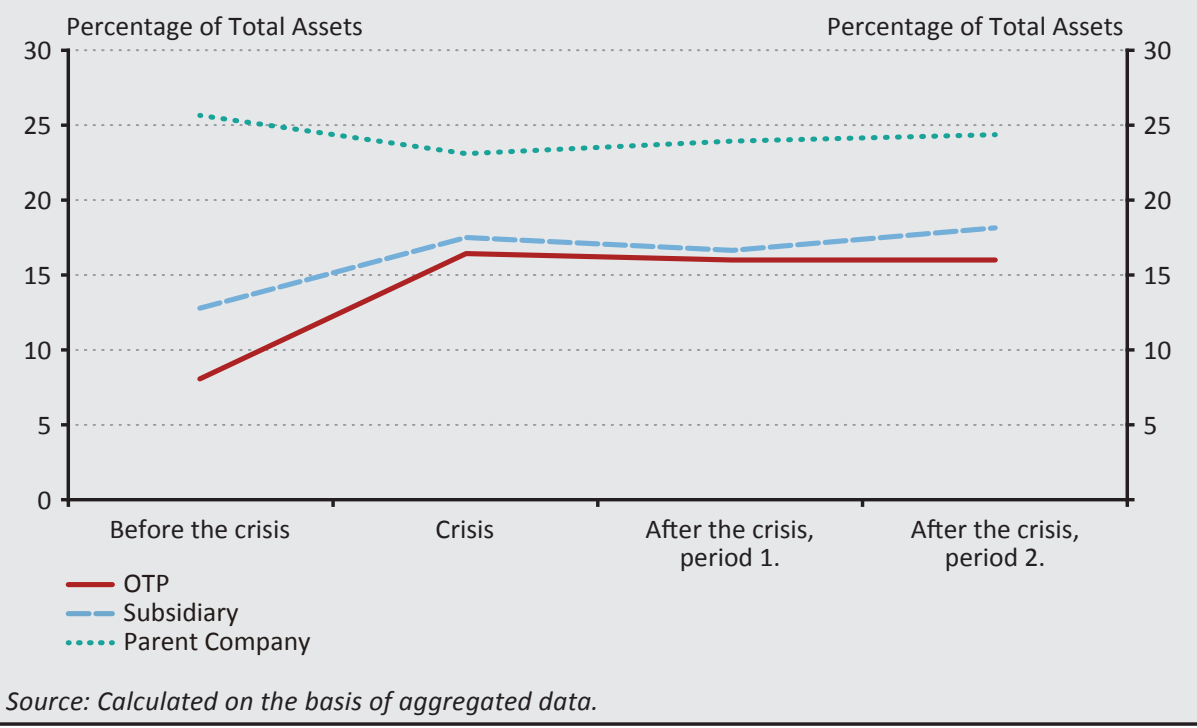




\section{Figure 2}

Temporal change of fair value involvement on the liability side as a percentage of the balance sheet total

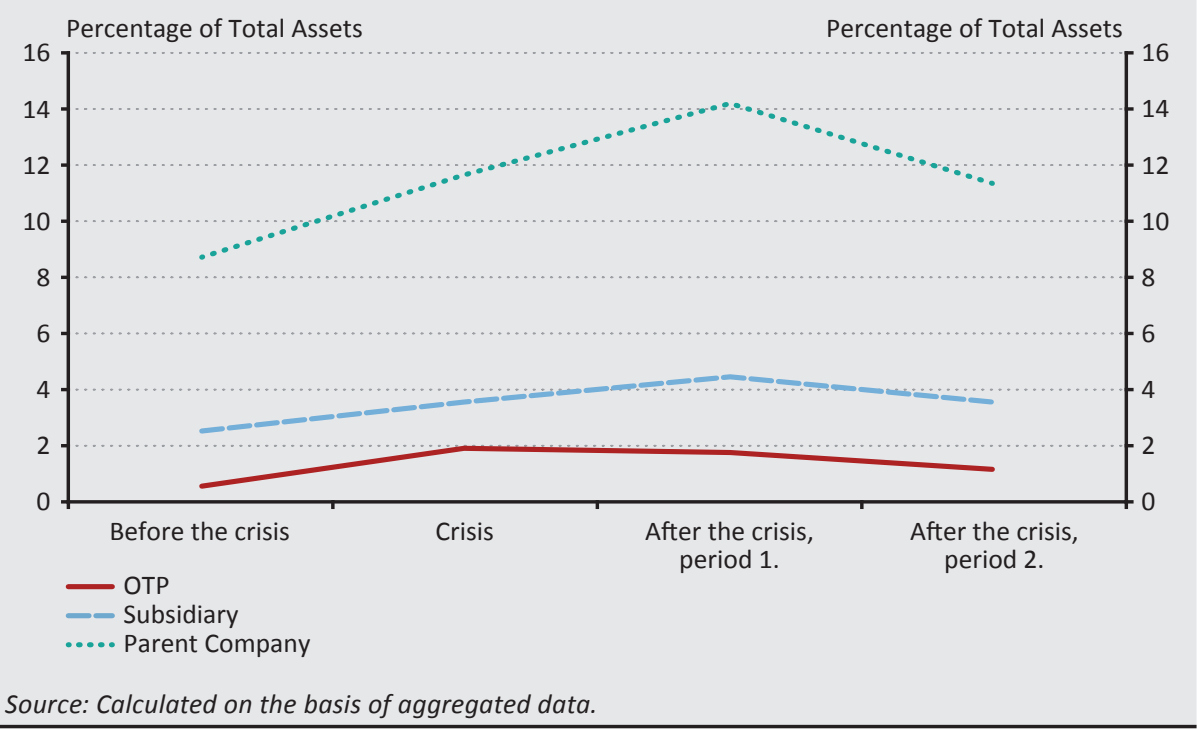

If we also consider the level structures of fair valuation, we get even more perfect involvement data (secondary involvement).

\section{Table 4}

Source: Calculated on the basis of aggregated data.

\begin{tabular}{l|c|c|c}
\multicolumn{1}{c|}{ Weight of Level 1 within the assets involved } & OTP & SUBSIDIARY & PARENT \\
\hline Pre-crisis & $63.79 \%$ & $47.75 \%$ & $51.06 \%$ \\
\hline During the crisis & $87.14 \%$ & $49.43 \%$ & $47.49 \%$ \\
\hline First post-crisis period & $58.83 \%$ & $48.83 \%$ & $44.17 \%$ \\
\hline Second post-crisis period & $78.39 \%$ & $72.13 \%$ & $54.10 \%$ \\
\hline \multicolumn{1}{c|}{ Weight of Level 2 within the assets involved } & OTP & SUBSIDIARY & PARENT \\
\hline Pre-crisis & $20.12 \%$ & $50.34 \%$ & $42.65 \%$ \\
\hline During the crisis & $9.66 \%$ & $49.41 \%$ & $48.54 \%$ \\
\hline First post-crisis period & $40.86 \%$ & $49.48 \%$ & $51.50 \%$ \\
\hline Second post-crisis period & $21.17 \%$ & $27.19 \%$ & $43.00 \%$ \\
\hline \multicolumn{1}{c|}{ Weight of Level 3 within the assets involved } & OTP & SUBSIDIARY & PARENT \\
\hline Pre-crisis & $16.09 \%$ & $1.91 \%$ & $7.20 \%$ \\
\hline During the crisis & $3.20 \%$ & $1.16 \%$ & $3.97 \%$ \\
\hline First post-crisis period & $0.31 \%$ & $1.69 \%$ & $4.33 \%$ \\
\hline Second post-crisis period & $0.44 \%$ & $0.68 \%$ & $2.90 \%$ \\
\hline Source: Calculated on the basis of aggregated data & & & \\
\hline
\end{tabular}




\begin{tabular}{|c|c|c|c|}
\hline \multicolumn{4}{|c|}{$\begin{array}{l}\text { Table } 5 \\
\text { Weight of fair valuation by levels within the liabilities involved }\end{array}$} \\
\hline Weight of Level 1 within the liabilities involved & OTP & SUBSIDIARY & PARENT \\
\hline Pre-crisis & $0.01 \%$ & $0.86 \%$ & $23.23 \%$ \\
\hline During the crisis & $0.11 \%$ & $1.62 \%$ & $9.87 \%$ \\
\hline First post-crisis period & $0.26 \%$ & $0.56 \%$ & $7.84 \%$ \\
\hline Second post-crisis period & $0.16 \%$ & $0.61 \%$ & $12.24 \%$ \\
\hline Weight of Level 2 within the liabilities involved & OTP & SUBSIDIARY & PARENT \\
\hline Pre-crisis & $99.99 \%$ & $96.99 \%$ & $68.70 \%$ \\
\hline During the crisis & $99.89 \%$ & $98.16 \%$ & $85.87 \%$ \\
\hline First post-crisis period & $95.47 \%$ & $96.45 \%$ & $87.77 \%$ \\
\hline Second post-crisis period & $99.84 \%$ & $99.25 \%$ & $85.59 \%$ \\
\hline Weight of Level 3 within the liabilities involved & OTP & SUBSIDIARY & PARENT \\
\hline Pre-crisis & $0.00 \%$ & $2.15 \%$ & $8.07 \%$ \\
\hline During the crisis & $0.00 \%$ & $0.22 \%$ & $4.26 \%$ \\
\hline First post-crisis period & $4.26 \%$ & $2.99 \%$ & $4.39 \%$ \\
\hline Second post-crisis period & $0.00 \%$ & $0.14 \%$ & $2.16 \%$ \\
\hline
\end{tabular}

\subsection{Most important results of the empirical analysis in respect of the primary involvement (Figures 1 and 2)}

- The involvement is substantially higher on the asset side than on the liability side. This finding is independent both from the period and the classification. Obviously, this also follows from the feature of the balance sheet, since on the liability side the equity cannot be valued at fair value.

- The involvement of the parent banks with international presence substantially exceeds the involvement of their subsidiaries and also that of OTP. This finding holds true in all periods under review, both on the asset and the liability sides. Accordingly, the degree of primary involvement can be traced back both to the size and the international nature.

- OTP is the least affect. This finding also applies to all periods and appears to be confirmed both on the asset and liability sides. OTP is not under any parent bank's "pressure" in respect of the valuation of the asset components. The parent company's instructions for sure play an important role in the development and valuation of the subsidiaries' asset structure.

- The OTP's fair value strategy on the asset side and the relation thereof to the crisis significantly differ from the parent banks' asset side fair value crisis strategy. The OTP's asset side primary involvement level before the crisis was by far the 
smallest. However, during the crisis it doubled and thereafter it practically stagnated. The parent banks' primary involvement was the highest before the crisis. It somewhat declined as a result of the crisis. However, thereafter it once again rises, albeit to a smaller degree.

- The subsidiary banks' primary involvement curves on the assets side resemble to that of OTP rather than of their own parent banks (see Figure 1). Accordingly, in the case of the international large banks we tend to designate more easily the possibility of fair valuation as an important medium leading to the crisis than in the case of the smaller Hungarian credit institutions, which settle for a follower strategy. Large banks are also characterised by higher willingness to take risks, as - compared to the balance sheet total - the ratio of those assets and liabilities that are valued at fair value is higher. Before and after the crisis there was no material change in the primary involvement compared to the balance sheet total.

- This suggests that the asset side fair value crisis strategy of the Hungarian credit institution sector differs from the international trends. Receivables from customers and other credit institutions are dominant asset components, which were valued at amortised historic cost.

- It is a reasonable question whether the different activity structure and the corresponding different balance sheet structure may alone explain the different fair value crisis strategy. For this we had to examine the ratio of the receivables and their change in time. We obtained the following results:

\begin{tabular}{|c|c|c|c|}
\hline \multicolumn{4}{|c|}{$\begin{array}{l}\text { Table } 6 \\
\text { Ratio of receivables (customers, credit institutions) to the balance sheet total }\end{array}$} \\
\hline & Subsidiary & Parent & ОтР \\
\hline Pre-crisis & $77.34 \%$ & $62.73 \%$ & $73.88 \%$ \\
\hline During the crisis & $71.21 \%$ & $63.11 \%$ & $72.20 \%$ \\
\hline First post-crisis period & $66.61 \%$ & $62.99 \%$ & $70.34 \%$ \\
\hline Second post-crisis period & $62.56 \%$ & $63.52 \%$ & $57.36 \%$ \\
\hline
\end{tabular}

It shows that the activity structure and the change thereof in time did not cause any tangible change in the parent banks' balance sheet structure. However, in case of the subsidiary banks a major structural change occurred, which was joined by OTP, although with a small delay, but more dynamically.

Obviously this clearly traceable trend can be attributed to several factors: the frozen credit market, and /or the continuous phase-out, prepayment and final repayment of the foreign currency loans, etc. However, the analysis of this is beyond the scope of this paper. However, it can be stated that substantial differences in the balance 
sheet structure of the parent and subsidiary banks are more typical before the crisis. This is not the case after the crisis. Due to this, in the case of the parent banks the ratio of the financial assets valued at fair value was perceivably higher only before the crisis. The answer to our question cannot be deemed straightforward by far, hence the problem needs further analysis.

The same question arises in respect of the hedging transactions: i.e. whether the difference in the fair value crisis strategy can be attributed to the different ratio of those. Having analysed this question as well, we came to the conclusion that it cannot, as the share of hedging transactions is marginal in the Hungarian subsidiary banks' balance sheets. It is hardly higher in the balance sheets of the parent banks:

\section{Table 7}

Change in the ratio of hedging transactions in time

\begin{tabular}{|c|c|c|c|c|c|c|}
\hline \multirow{3}{*}{$\begin{array}{l}\text { Description } \\
\text { Pre-crisis }\end{array}$} & \multicolumn{2}{|c|}{ Assets } & \multicolumn{2}{|c|}{ Liabilities } & Assets & Liabilities \\
\hline & Subsidiary & Parent & Subsidiary & Parent & \multicolumn{2}{|c|}{ OTP } \\
\hline & $0.54 \%$ & $0.44 \%$ & $0.40 \%$ & $0.48 \%$ & $0.09 \%$ & $0.15 \%$ \\
\hline During the crisis & $0.34 \%$ & $0.91 \%$ & $0.14 \%$ & $0.73 \%$ & $0.14 \%$ & $0.70 \%$ \\
\hline First post-crisis period & $0.40 \%$ & $1.32 \%$ & $0.43 \%$ & $1.23 \%$ & $0.13 \%$ & $0.85 \%$ \\
\hline Second post-crisis period & $0.61 \%$ & $0.88 \%$ & $0.25 \%$ & $1.06 \%$ & $0.23 \%$ & $0.69 \%$ \\
\hline Average (2006-2015) & $0.49 \%$ & $0.88 \%$ & $0.31 \%$ & $0.90 \%$ & $0.15 \%$ & $0.56 \%$ \\
\hline
\end{tabular}

Source: Calculated on the basis of aggregated data.

\subsection{Most important results of the empirical analysis in respect of the secondary involvement (see: Tables 4 and 5)}

\subsubsection{Temporal trends}

Compared to the pre-crisis situation, in the subsequent periods (particularly in the second period of the stabilisation) we can see on both the asset and liability sides that the role of Level 3 substantially dropped, i.e. there are distinct efforts on both sides of the balance sheet by the market participants to transform the internal structure of their fair value involvement at the expense of Level 3. This reaction may be clearly interpreted as risk mitigation, or at least it carries a clear message to the potential investors, promising the cleaning of the balance sheets form the "elements of higher risk". Surprisingly, this impact is less strong in the relation to the subsidiaries and OTP than in case of parent banks, which essentially can be attributed to two reasons. On the one hand, to the independent decisions of the banks, and to the other hand, to the changes in the Hungarian financial legislation. This is particularly true for OTP. Namely, during 2010 the bonds issued in the Hungarian municipality sector were reclassified as loans. Unfortunately, no active market developed in Hungary for municipal bonds, hence the credit institutions were unable to allocate a relevant market value to these bonds. Based 
on the analysis of the accounting content of the given instrument they found that these instruments satisfy the IAS 39 standard, i.e. they can be defined as loans/ receivables; thus, from that time they were valued at amortised historic cost rather than at fair value. Another effect is the valuation changes based on the banks' individual decisions, which in case of OTP was attributable to the hedging transactions elaborated for covering the exchange rate risk of the foreign currencydenominated mortgage loans. Upon the valuation of the cross-currency interest rate swaps, due to the speculations related to the EUR/CHF spreads, the bank deemed the market quotes less reliable, hence it decided to reallocate the respective portfolio from Level 2 to Level 3. In 2012, with the improvement in the quality of information, it was reclassified as Level 2. The situation was similar in case of the subsidiaries as well. The hedging transactions' value was measured by model-based valuation instead of the market-based measurement. This explains the slightly rising data of the given period.

During the crisis (2008-2009) and in the period thereafter (2010-2011) the parent companies typically demonstrated prudency in the area of fair valuation. They reviewed the reliability of the value of their assets and liabilities, allocated to Level 1 , valued purely on the basis of market information. The reliability of the business and market information in that period was highly questionable. Due to the general rise in volatility, certain instruments were hit by major price or exchange rate fluctuations; thus, the trust in the results of the repeatedly performed valuations was shaken. Due to the ambiguous results, the valuation purely based on market information was increasingly replaced by the adjusted valuation, supplemented by financial models. We can see this in the rise in the assets' (Table 4) Level 2 ratios compared to the previous period. In the post-crisis period these effects disappeared and the process took a reverse direction. Once again the ratio of Level 1 increased at the expense of Levels 2 and 3, as the market data became increasingly reliable and the volatility decreased.

Despite the special domestic effects, we can state as a fact that in the Hungarian credit institution sector the weight of Level 3 in the second post-crisis period is generally materially lower than before the crisis, i.e. albeit with a small delay we follow the efforts and trends of risk elimination, appearing more strikingly at the parent banks.

\subsubsection{Structural trends of the balance sheet and the fair valuation levels}

On the asset side we can see that by the end of the period under review, all actors raised the weight of Level 1 above the pre-crisis index. Thus, Level 1 clearly has a dominant role in the fair value involvement, which is attributable to the improvement in the reliability of market information and to the clear effort that the Hungarian credit institution actors regarded it as one way to recover from the 
crisis to modify the balances sheet and fair value level structure in such a way that clearly delivers the message to the investors on the intention to reduce risks.

This is how they intended to comply to a higher degree with the standard's requirements related to fair valuation, according to which the economic agent that wishes to apply it should do its best to use reliable market information for the valuation to the highest possible degree.

The dominant role of Level 2 is evident on the liability side. This is primarily attributable to the hedging transactions, in the valuation of which the market data is an important element, which is not necessarily available directly. The final balance sheet value can be determined by deriving it from the market price and rate of other instruments, after performing the necessary adjustments. Anyway, the deployment of the valuation methodology machinery is necessary to some degree in all cases. Very similar structural changes occurred on the liability side as on the asset side.

Accordingly, our findings correspond to the correlations identified in the technical literature. The crisis clearly has an influence on the fair valuation strategy, as it evokes such adjustment mechanisms, the key objective of which is to reduce the additional risk inherent in fair valuation. This also means that the fair valuation strategy indirectly reacts upon the crisis, as it exerts an influence on the level of market risk. In this sense, particularly the weight of Level 3 may play a material role as potential means of recovering from the crisis.

\subsection{Fair value involvement as risk indicator}

We also examined the role of the individual levels in the periods under review on the asset and liability sides of the balance sheet. In this respect we paid special attention to Level 3, as this bears the highest risks, because at this level the valuation is performed by models. We restricted the analysis to the asset side, because on the liability side the weight of Level 3 compared to the prevailing balance sheet total is negligible.

This is already a sufficiently aggregated and optimised indicator, which may rightly be treated as the risk indicator of the fair valuation involvement, also reflecting the weight of the "risky items" in the balance sheets (asset side). This indicator, boiling down the additional risk of fair valuation to a single figure, may be suitable to deliver important information to the investors on the credit institution's real accounting policy and the impact thereof on the exposure.

It is very easy to calculate it: the primary and secondary involvement indicators must be multiplied by each other at each level; thus, obtaining the weight of the individual levels compared to the balance sheet total.

On the asset side we try to present the role of Level 3, since this level may carry the highest investment risk due to its content. 


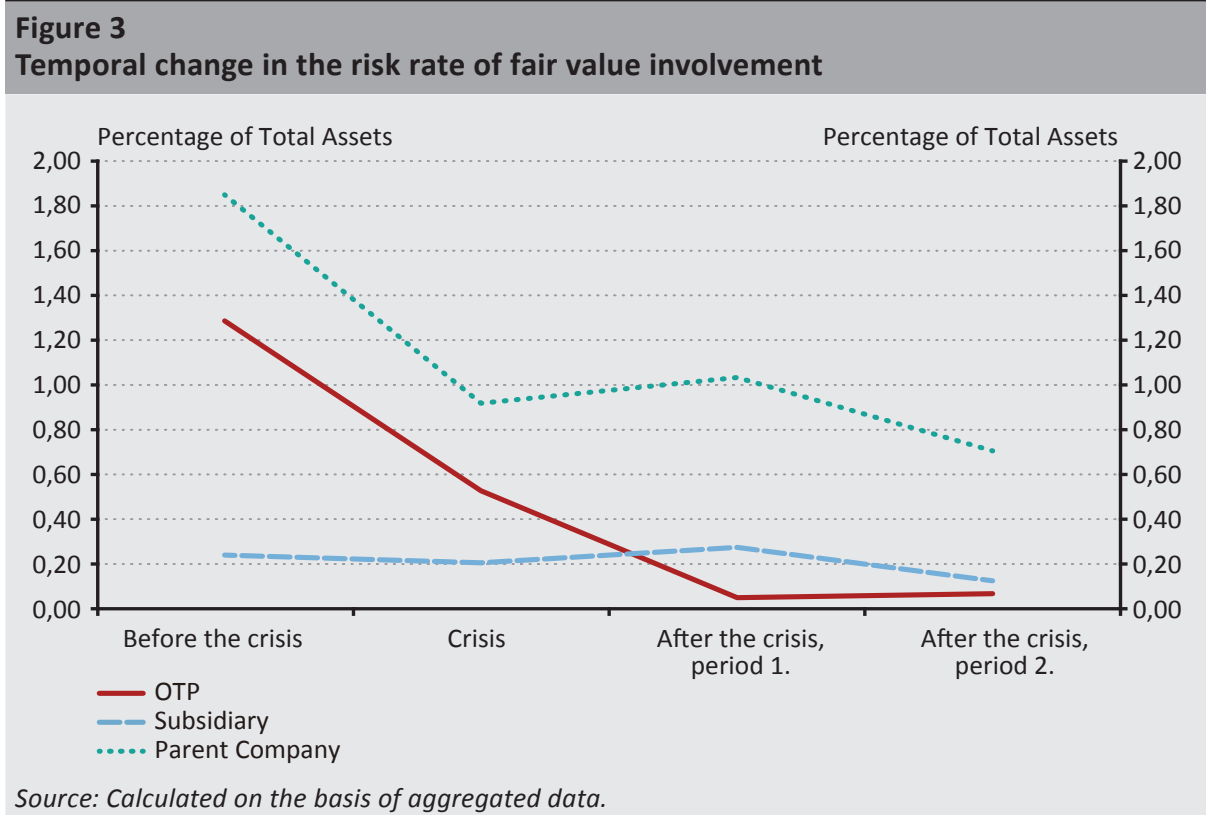

The trends are clearly reflected by Figure 3. Before the crisis, the international parent banks relied on the possibility of Level 3 to a substantially larger extent than their Hungarian subsidiaries or OTP. Essentially, this difference did not change during or after the crisis; however, it is a major difference that after the crisis the inherent risk halved, as the weight of Level 3 is hardly half of the pre-crisis indicator.

The reaction of the actors was extremely fast. They tried to shift a large part of their assets subject to fair valuation on Level 3 towards Level 1 and 2, which continuously reduced the role and weight of Level 3 in their balance sheets. The subsidiaries' and OTP's risk of this type became balanced, while the parent banks' exposure (ratio to the balance sheet total) is still almost six times higher than the Hungarian average.

If we also consider the magnitude of the balance sheet totals and not only the ratios to those, then according to our estimation (calculating with the prevailing average annual foreign currency exchange rates), on the asset side of the parent banks' balance sheets the amount affected by Level 3 was on average around EUR 140 million before the crisis, which fell back to one-third by the 4th period. Compared to this, the involvement of the domestic subsidiaries and OTP was negligible. 


\section{Summary and outlook}

According to our finding, the fair value involvement can be measured at three levels:

- primary involvement means the ratio of the individual balance sheet items to the balance sheet total, which is the primary point of orientation on the scope of fair valuation;

- secondary involvement is when the structure of the involvement is measured at the levels of fair valuation, also as ratio of the balance sheet total;

- in our opinion, the fair valuation involvement, as risk indicator, can be applied, if we express the weight of Level 3 on the asset side as a ratio of the balance sheet total.

As regards the debate in the technical literature on the relation between fair valuation and the crisis, we can add that in the Hungarian credit institution sector the crisis generated clearly demonstrable adjustment mechanisms, which were realised in the fall of additional risks inherent in the fair value involvement.

We found that in case of the parent banks and their subsidiaries the adjustment took place not at the same pace and not in a homogenous manner. In our view this may have been mostly attributable to the fact that the Hungarian actors did not capitalise on the fair valuation opportunities to the same degree as the parent companies covered by the analysis.

We explain this finding by the material differences in the ratio of assets valued against profit/loss and - within equity - against the valuation reserve ${ }^{9}$, which are as follows:

\section{Table 8}

Average ratios of recognitions against profit/loss versus, within equity, against the valuation reserve $(\mathrm{OCI})$ in the period under review

\begin{tabular}{l|c|c|c} 
Description & Subsidiary & Parent & OTP \\
\hline Ratio of assets valued against profit/loss & $20.34 \%$ & $59.88 \%$ & $11.43 \%$ \\
\hline Ratio of assets valued against OCI & $79.66 \%$ & $40.12 \%$ & $88.57 \%$ \\
\hline
\end{tabular}

Source: Calculated on the basis of aggregated data.

It is clear that the domestic subsidiaries (and OTP), as mentioned before, prefer the more prudent valuation methods. By contrast, in respect of the recognition of the valuation difference, the parent companies give preference to recognition against

\footnotetext{
${ }^{9}$ Components valued against Other Comprehensive Income $(\mathrm{OCI})$ according to the international technical
} literature. 
profit/loss. Thus, parent companies capitalise on the flexibility provided by fair valuation more often than the Hungarian subsidiaries.

Obviously, we do not regard our research as completed. In many respects it left at least as many questions open as the number of questions it answered. Accordingly, several publications are yet to follow, as the value relevance analyses and the value measurement practice outside the credit institution sector can still contribute a lot to the general acceptability of our findings; thus, our research will be focused on this in the near future.

\section{References}

Allen, F. - Carletti, E. (2008): Mark-to-Market Accounting and Liquidity Pricing. Journal of Accounting and Economics, 45(2-3): pp. 358-378. https://doi.org/10.1016/j. jacceco.2007.02.005.

Bagna, E. - Di Martino, G. - Rossi, D. (2014): An Anatomy of The Level3 Fair Value Hierarchy Discount. DEM Working Papers Series from University of Pavia, Department of Economics and Management. No 65:46. https://papers.ssrn.com/sol3/papers.cfm?abstract_ id=2367405. Downloaded: 15 November 2016.

Barth, M. E. - Gómez-Biscari, J. - López-Espinosa, G. (2012): Fair Value Accounting, Earnings Management and the use of Available-for-Sale Instruments by Bank Managers. Working Paper, Universidad de Navarra, N05/12: pp. 1-52.

Barth, M., (2004): Fair Values and Financial Statement Volatility. In: Borio, C. - Hunter, W.C. - Kaufman, G. G - Tsatsaronis, K. (ed.): The Market Discipline Across Countries and Industries. Cambridge, Massachusetts, MIT Press: 323-333.

Bélyácz, I. (2013): A befektetések és a tökepiac (Investments and Capital market). Akadémiai Kiadó, Budapest.

Beneish, M. D. (1999): The detection of earnings manipulation. Financial Analysts Journal, 55: pp. 24-36. https://doi.org/10.2469/faj.v55.n5.2296.

Bosch, P. (2012): Value relevance of the fair value hierarchy of IFRS 7 in Europe - How reliable are mark - to - model fair values? Working Papers University of Fribourg, SES, 439: pp. 1-36.

Bromwich, M. (2007): Fair values: imaginary prices and mystical markets. In: P. Walton (editor): The Routledge Companion to Fair Value and Financial Reporting, Routledge/ Taylor \& Francis Group, London: pp. 46-67. https://doi.org/10.4324/NOE0415423564.ch5.

Christensen, H. B. - Nikolaev, V. V. (2013): Does Fair Value Accounting for Non-Financial Assets Pass the Market Test? Review of Accounting Studies January: pp. 734-775. https:// doi.org/10.1007/s11142-013-9232-0. 
Goh, B. W. - Ng, J. - Yong, K. O. (2009): Market pricing of banks' fair value assets reported under SFAS 157 during the 2008 economic crisis. Working Paper, Massachusetts Institute of Technology and Singapore Management University.

Gorton, G. B. (2008): The Panic of 2007. NBER Working Paper No. 14358. September: pp. 1-91. https://doi.org/10.3386/w14358.

Greenberg, M. D. - Hellen, E. - Clancy, N. - Derteuzos, J. N. (2013): Fair value accounting, historical cost accounting and systemic risk. RAND Corporation.

Hitz, J. M. (2005): The Decision Usefulness of Fair Value Accounting - A Theoretical Perspective. European Accounting Review, vol. 16, issue 2: pp. 323-362.

Kolev, K. (2008): Do investors perceive marking-to-model as marking-as-myth? Early evidence from FAS 157 disclosure. https://doi.org/10.2139/ssrn.1336368.

Kovács, D. M (2012): A valós értékelés új keretrendszere a nemzetközi pénzügyi beszámolásban (New framework of fair valuation in the international financial reporting). Financial and Economic Review. 2: pp. 161-181.

Laux, C. - Leuz, C. (2009a): Did Fair-Value Accounting Contribute to the Financial Crisis? Journal of Economic Perspectives, Vol. 24, issue 1: 93-118. http://doi.org/10.1257/ jep.24.1.93.

Laux, C., - Leuz, C. (2009b): The crisis of Fair value accounting: making sense of the recent debate. Accounting, Organisations and Society, vol. 34, August (6-7): pp. 826-834.

Le Pan, N. (2008): Whither Financial Regulation? Bank of Canada. A Festschrift in Honour of David Dodge. November: pp. 25-78.

Magnan, M. (2009): Fair Market Value and the Financial Crisis: Messenger or Contributor? Accounting Perspectives 8(3): pp. 189-213. https://doi.org/10.1506/ap.8.3.1.

McFarland, J. - Partridge, J. (2008): Mark-to-market' accounting rules fuel debate. The Globe and Mail Report on Business. 20 November https://www.theglobeandmail.com/reporton-business/mark-to-market-accounting-rules-fuel-debate/article1350755/. Downloaded: 15 November 2016.

Pitz, M. - Schepp, Z. (2013): A banki hitelek árazásának vizsgálata strukturális VAR modell segitségével (Analysis of the pricing of bank loans relying on the structural VAR model). Pénzügyi Szemle 58(4): pp. 434-447.

Power, M. (2010): Fair value accounting, financial economics and the transformation of reliability. Accounting and Business Research, 40(3): pp. 197-210. https://doi.org/10.10 80/00014788.2010.9663394. 
Pozen (2009): Is It Fair to Blame Fair Value Accounting for the Financial Crisis? HBR, November: pp. 1-10.

Rérolle, J.F. (2008): The fair value debate: from accounting utopia to financial realism. Revue Trimestrielle de Droit Financier no. 4: pp. 1-12.

Riedl, E. J. - Serafeim, G. (2011): Information Risk and Fair Value: An Examination of Equity Betas. Journal of Accounting Research 49: pp. 1083-1122. https://doi.org/10.1111/j.1475679X.2011.00408.x.

Sarkozy, M.N. (2008): International financial crisis. Speech by M. Nicolas Sarkozy, President of the Republic, 25 September.

Shaffer, S. (2012): Evaluating the Impact of Fair Value Accounting on Financial Institutions: Implications for Accounting Standards Setting and Bank Supervision. Federal Reserve Bank of Boston. WPS No. QAU 2012-01: pp. 1-60.

Shamkuts, V. (2010): Fair Value Accounting. BS Thesis, University of Iceland. https:// skemman.is/bitstream/1946/4234/1/Thesis_fixed.pdf. Downloaded: 15 November 2016.

Song, C. J. - Thomas, W. B. - Yi, H. (2010): Value relevance of FAS No. 157 fair value hierarchy information and the impact of corporate governance mechanisms. The Accounting Review, 85(4): pp. 1375-1410. https://doi.org/10.2308/accr.2010.85.4.1375.

Takács, A. (2015): Vállalatértékelés magyar számviteli környezetben (Company valuation in the Hungarian accounting environment). Second, enlarged edition, Perfekt.

Takács, A. (2014): The Relationship between Appraised Company Values and Future Stock Prices in the International Banking Sector. International Research Journal of Finance and Economics, 118: pp. 113-123.

Veron, N. (2008): Fair Value Accounting is the Wrong Scapegoat for this Crisis. European Accounting Review, 5(2): pp. 63-69. https://doi.org/10.1080/17449480802510542.

Wallison, P. J. (2008): Fair value accounting: A critique. American Enterprise Institute for Public Policy Research Outlook Series: pp. 1-8.

Whalen, R. C. (2008): The subprime crisis: causes, effect and consequences. Networks Financial Institute Policy Brief No. 2008-PB-04. https://doi.org/10.2139/ssrn.1113888. 